\title{
The belowground intersection of nutrients and buoyancy in a freshwater marsh
}

\author{
R. Eugene Turner · James E. Bodker $\cdot$ Christopher Schulz
}

Received: 13 September 2016/Accepted: 10 July 2017/Published online: 17 July 2017

(C) The Author(s) 2017. This article is an open access publication

\begin{abstract}
An oligotrophic coastal freshwater marsh converted to open water within months after receiving partially-treated sewage water in fall 2006. Rafts of the upper $60 \mathrm{~cm}$ of marsh soil were found throughout the area within two years, as parts of the 1100 year-old marsh were re-distributed in the open water. We examined the marsh soils from 2009 to 2012 to determine some of the cause-and-effect consequences of their decomposition to the formation of these floating mats. There was a lack of herbivory damage in April 2009 where the outer boundary of the soil profile was weakened at $50-60 \mathrm{~cm}$ depth, and eventually converted to open water. A 2012 storm event flooded the area by $1.5 \mathrm{~m}$, resulting in new marsh mat 'popups' whose bottom underside was coincidental with the layer of maximum decline in soil strength in the sewage treated area. We conclude that the addition of partially-treated sewage weakened the soil structure during this high water event and others to allow for the
\end{abstract}

Electronic supplementary material The online version of this article (doi:10.1007/s11273-017-9562-y) contains supplementary material, which is available to authorized users.

R. Eugene Turner $(\bowtie) \cdot$ J. E. Bodker

Department of Oceanography and Coastal Sciences, Louisiana State University, Baton Rouge, LA 70803, USA

e-mail: euturne@1su.edu

C. Schulz

Department of Biological Sciences, Southeastern

Louisiana University, Hammond, LA 70402-10736, USA vertical separation of the marsh as the buoyancy forces exceeded the marsh's anchor strength, thereby exposing the softer older peats to decomposition, and smothering marsh underneath the mat's new location. A chronic effect of eutrophication on these marshes was, therefore, revealed in a dramatic flooding event. A bottom up (nutrient addition), not top-down stress (herbivory) contributed to wetland loss in the area, and is a potentially significant chronic stressor for other eutrophied marshes with significant aboveground flooding.

Keywords Eutrophication - Freshwater marsh . Panicum hemitomon - Buoyancy · Floating mat - Soil strength

\section{Introduction}

Tidal coastal marshes are well-known for attributes such as habitat value, storm protection, and carbon sequestration (Reddy and DeLaune 2008; Barendregt et al. 2009; Keddy 2011; Mitsch and Gosselink 2015). Field and laboratory experiments in a variety of habitats indicate a plethora of eutrophication effects on coastal marshes both above- and belowground (e.g., Hanson et al. 2016; Deegan 2002). These effects include altered community composition, higher aboveground biomass, decreased belowground biomass of live roots (Darby and Turner 2008), adjustments to the 
elemental composition of prey in water and marsh (Denno et al. 2003; Turner 2002), and altered plant structure (Liu et al. 2016). Decomposition is, in general, enhanced by increased nutrient availability (Webster and Benfield 1986; Enríquez et al. 1993; Kominoski et al. 2015; Rosemond et al. 2015).

The enhanced decomposition rates are linked to a reduced soil strength and large scale conversion of freshwater and salt marshes to open water (Swarzenski et al. 2008; Turner 2011; Kearney et al. 2011). The conversion can happen through (1) the direct loss of soil organic material by decomposition in situ (Boar et al. 1989; Bodker et al. 2015), and (2) as an enhanced susceptibility to scouring and lift off through chronic and episodic high energy hydrologic events (Cypert 1972). Gas formation, when trapped, lowers the soil bulk density and increases buoyancy (Hogg and Weins 1988a, b). Methane, for example, is found to significantly increase in constructed peatland marshes (Mander et al. 2014). Higher rates of herbivory, however, might also be stimulated to graze excessively on the nitrogen-enriched forage and become a top-down influence (Ialeggio and Nyman 2014).

Both bottom-up and top-down pathways of marsh degradation may act independently of one another or synergistically. What is needed is to test the relative strength of these two contrasting hypotheses for marsh loss (top-down or bottom-up). This was done when a stable and homogenous expanse of Panicum hemitomon marsh converted to open water after the introduction of partially-treated sewage into it creating four major consequences (Bodker et al. 2015): (1) Nutrient-rich water elevated marsh soil decomposition, (2) inserted cellulose strips decomposed faster closest to the partially-treated sewage introduction, (3) the decomposition of belowground soil organic matter was more rapid with the addition of the partially-treated water, and (4) decomposition rates increased in proportion to increasing tissue nitrogen: phosphorus content. Nitrogen, not phosphorus, appears to be the major factor enhancing decomposition. Here we report on field examinations meant to determine if the enhanced decomposition rates, combined with the upward pull of mat buoyancy, was sufficient to exceed the soil strength holding it together. We also examined if marsh loss happened where there was no evidence of macrofaunal grazing before the loss.

\section{Methods}

Study area

The study area is located in the Lake Pontchartrain Basin watershed, just south of Hammond, Louisiana (USA), and is referred to locally as the Four-Mile Marsh. This is near the City of Ponchatoula and one of several freshwater marshes in a series aligned east to west, and south of the Baton Rouge, Louisiana, geological fault line (Fig. 1) that have been fragmented by roadway and drainage construction. These are seaward of a Pleistocene terrace edge and overlie the mineral remnants of a former embayment of the Gulf of Mexico. Bottom sediment matter was dated as 1100 years \pm 100 years old (uncalibrated; Bodker et al. 2015).

The Four-Mile Marsh, like the other freshwater marshes in this area, was an emergent marsh anchored to the mostly sand-clay layer beneath as of November 2006. There was no significant area of open water then, and it was a continuous vegetative cover of herbaceous perennials, esp. P. hemitomon (Bodker et al. 2015). P. hemitomon was once $25 \%$ of the areal coverage of freshwater marsh vegetation in coastal Louisiana (Chabreck 1972) and is a keystone species forming a homogenous plant community of roots and rhizomes that may or may not be attached to the soil beneath. The general drainage of the marsh is southwesterly through a series of drainage culverts emptying into an Interstate highway borrow canal, and southerly through a largely cypress-tupelo wetland. These marshes are part of the State of Louisiana's Joyce Wildlife Management Area (WMA) and are almost entirely surrounded by forested wetlands (Fig. 1). Water fluctuations can be $0.5 \mathrm{~m}$ and are dependent on wind direction and strength. The soil is organic matter.

The South Slough waterway hydrologically separates the Four-mile Marsh into a northern section and a larger southern section receiving 4-6 million gallons $\mathrm{d}^{-1}$ of permitted sewage from the City of Hammond, Louisiana (Hunter et al. 2009). Aerial imagery from the first photographs taken in the 1930s to before effluent was first added, in November 2006, showed no clear differences between any marsh within the study area (including reference marshes); all marshes appeared without open water areas within them (Bodker et al. 2015; see Fig S1, Supporting 


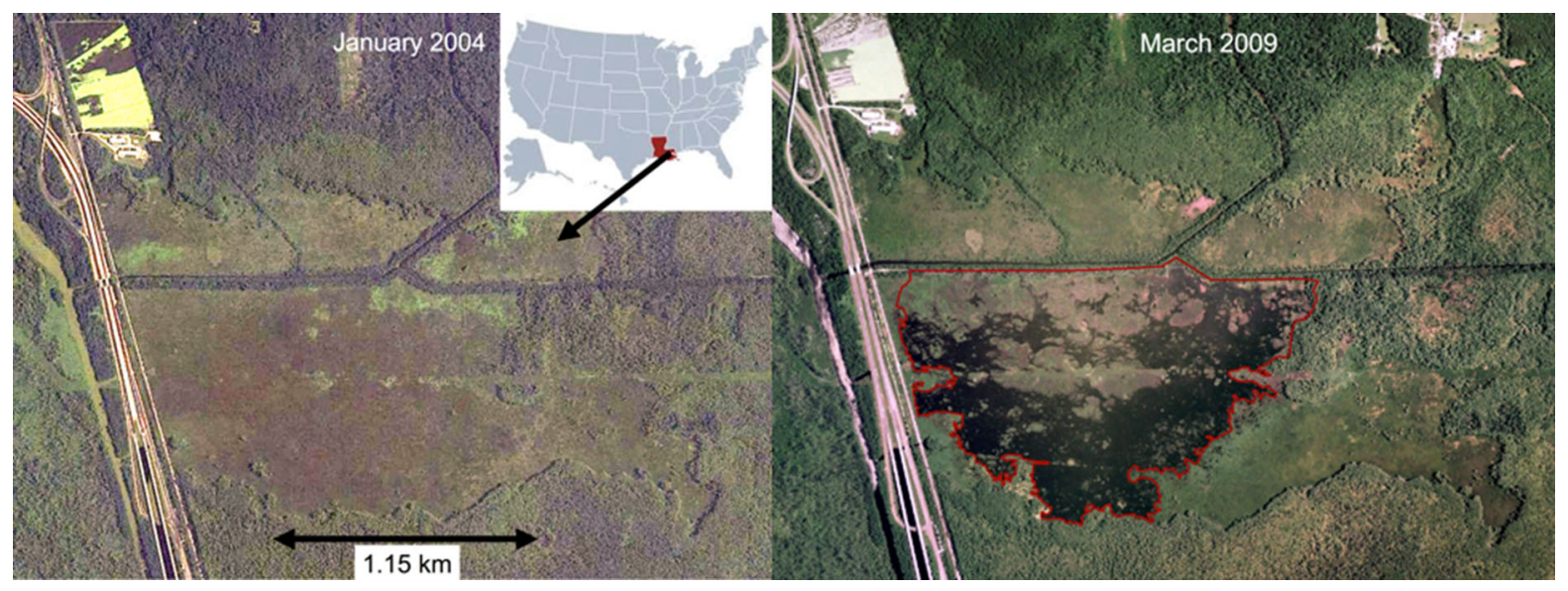

Fig. 1 The marsh site in January 2004 (left) and March 2009 (right). The marsh is the brown area and is surrounded by trees. Interstate 55 is north to south on the left side (white), and a levee

Information). Continuous effluent began discharging into the marsh in November 2006. Bright green vegetated areas were noticeable in the discharge area by September 2007 and extended $500 \mathrm{~m}$ south. Open water started forming behind this green area as it expanded until it reached parts of the wetland forest edge $1 \mathrm{~km}$ south of the effluent outfall. Much of the marsh appeared as open water by March 2009. Today is it is a 122 ha area of open water and aquatic floating annuals. The surrounding marshes to the east and southeast are hydrologically isolated from the sewage effluent, and remained unaltered and stable in this interval, and no ponding was visible within them as of July 2016. Patches of $S$. lancifolia expanded in the effluent area and grew to an exaggerated size during 2007, but were later supplanted by the more dominant annual floating plants.

Soil strength

We measured the soil strength of marsh soils with a Dunham E-290 Hand Vane Tester using a $20 \times 40 \mathrm{~mm}$ vane. The in situ readings of the peak shear vane strength were recorded on a calibrated scale built into a head assembly directly attached to a steel rod fitted to the vane at the terminal end. A handle is used to both insert the vane to the desired depth and to apply the shearing torque. The skin friction estimates used a measuring rod without vanes and was always less than $1 \mathrm{kPa}$ (kilo Pascal). Five replicate measurements were made at each of three locations in spring road runs north to south in the middle. A red line in the 2009 photo outlines the disturbed area at that time

2010 that were within $20 \mathrm{~m}$ of the eroding edge that became open water by 2011 . There was no evidence of significant macrofaunal grazing before or after it converted to open water. These soil strength measurements were compared to replicate measurements at each of five marsh sites that did not erode located $>500 \mathrm{~m}$ from the eroding marsh sites. We used this transect data to test if soil strength was different near and further from the where the partially-treated sewage water additions occurred. All the soil strength measurements are reported as the mean \pm 1 Standard Error $(\mu \pm 1$ SE).

\section{Mat thickness}

Hurricane Isaac, a Category 1 hurricane with sustained winds of $130 \mathrm{~km} \mathrm{~h}^{-1}$, made two landfalls on the Louisiana coastline on 28 and on 29 August, 2012. It passed in a southeast to north-northwesterly direction on a path $<50 \mathrm{~km}$ west of the study area, and pushed water in the northeast quadrant of the storm inland and towards the study area. The hurricane rainfall totals in the area were $16-40 \mathrm{~cm}$. There are no routinely maintained water level gages in the immediate area, but storm waters were $3 \mathrm{~m}$ higher than normal to the south of Interstate 12 (an east-west highway to the north of the study area), and $2 \mathrm{~m}$ high on the south side of Lake Maurepas. It was $2 \mathrm{~m}$ high at the New Canal station on the south side of Lake Pontchartrain and ranged from 1.75 to $3 \mathrm{~m}$ on the north shore (Berg 2013). Water at Pass Manchac, which connects Lakes 
Maurepas and Pontchartrain, was $2 \mathrm{~m}$ above normal on 31 August, 2012, and then dropped slowly over the next week (USACOE 2013).

We visited the marsh on 3 September 2012, two days after Hurricane Isaac landed on the coast, and when water was still $1.5 \mathrm{~m}$ over the marsh surface. We cored seven newly floating mats with a seamless stainless steel tube with a sharp coring end. We measured the thickness of mat in the holes by making four measurements at $90^{\circ}$ intervals along the cored mat walls. We also measured from the mat surface to the water that quickly filled the new hole in the mat.

\section{Aerial overflights}

Pre- and post Hurricane Isaac photographs were taken from a small airplane on 1 and 13 September 2012. Water was about $2 \mathrm{~m}$ over the marsh surface on 1 September 2012, and below the marsh surface on 13 September 2012.
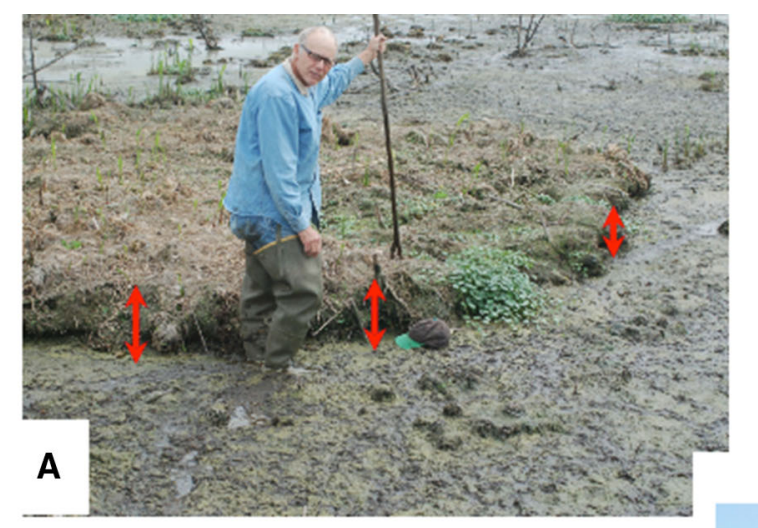

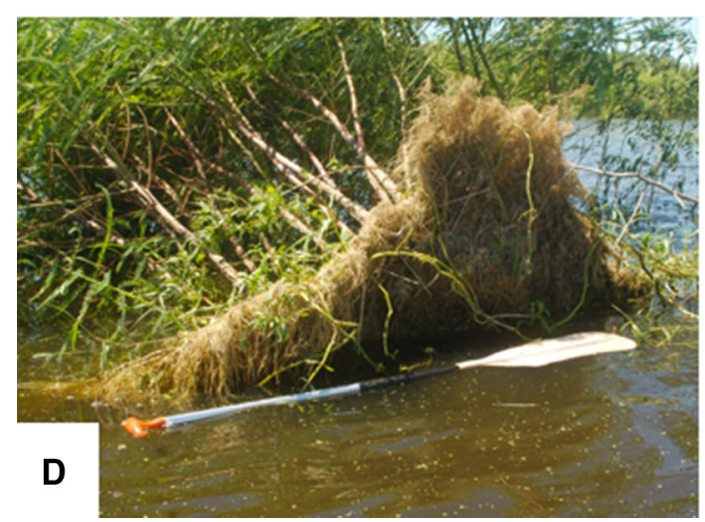

Fig. 2 The floating, emergent, barren and lodged vegetation. a Floating mat on top of marsh. b A recent dislodged mat on top of an eroded marsh, and $\mathbf{c}$ the hole it left behind. d A lodged

\section{Results}

Mat thickness

Floating mats were common throughout the area only after introduction of the partially-treated sewerage began (Fig. 2). These newly floated mats were about $40-50 \mathrm{~cm}$ thick, but of an uncertain age (Fig. 2a). Sometimes sharp features of the remnant hole from the donor marsh are conserved for a few weeks (Fig. 2b, c). Some floating patches of vegetation found after Hurricane Isaac appeared to be the same vegetation found within a few meters of other patches that remained anchored (Fig. 2e). Other vegetation, including Sesbania herbaria (coffee bean), grew in the exposed mudflat, but toppled over (lodging) at the end of the growing season (Fig. 2d). The average mat thickness of the mats newly floating after Hurricane Isaac was $59.6 \pm 1.3 \mathrm{~cm}(\mu \pm 1 \mathrm{SE})$ and there was about $5 \mathrm{~cm}$ of mat above the water surface.
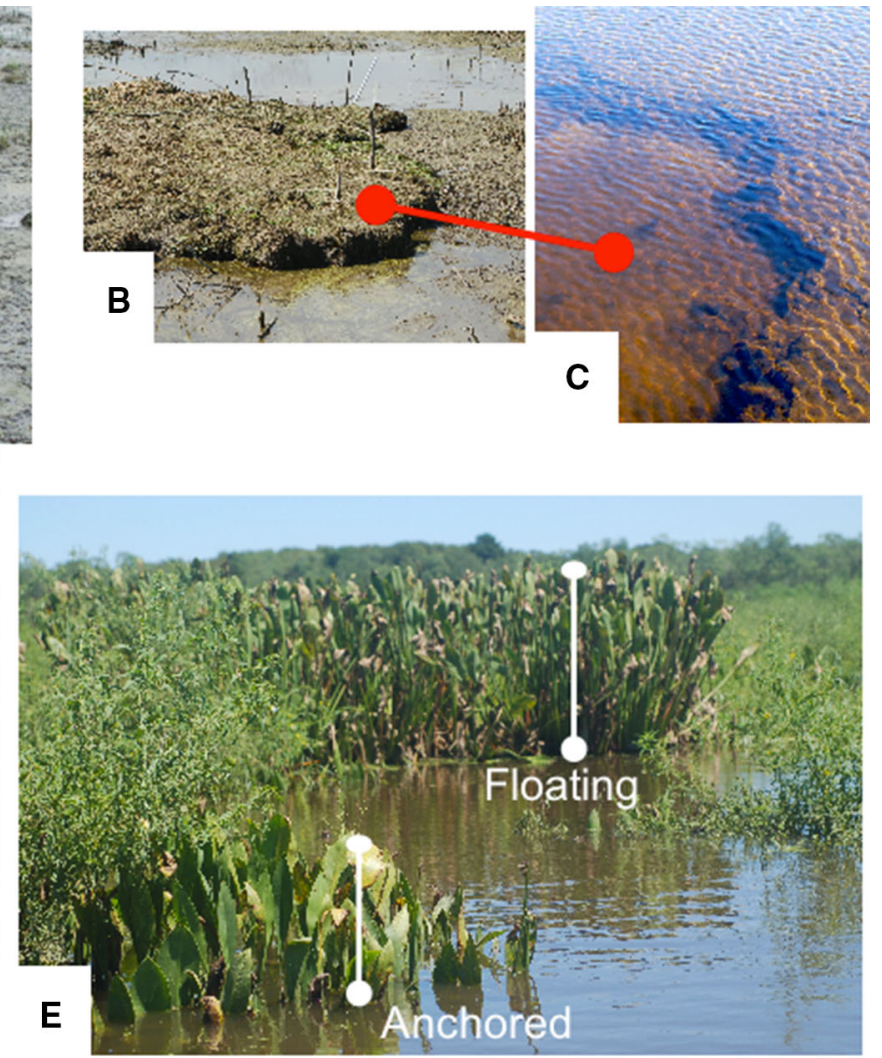

Sesbania herbaria (coffee bean); e anchored and floating Sagittaria lancifolia (duck potato) on the flooded marsh 


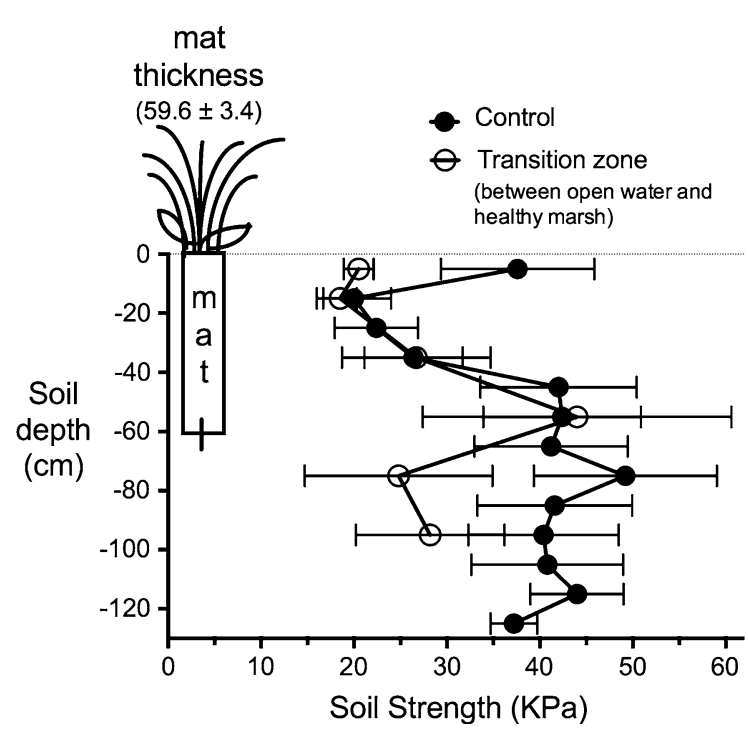

Fig. 3 The average soil strength $(\mathrm{kPa})$ for the control areas (every $10 \mathrm{~cm}$ ) and the transition zone (every $20 \mathrm{~cm}$ ) at the edge of the open water, to $50 \mathrm{~m}$ inland. The average thickness $(\mathrm{cm}$; $\mu \pm 1$ SE) of the mat sampled 3 September 2012 when the Hurricane Isaac flood waters were $1.5-2.0 \mathrm{~m}$ over the marsh. The mat was $>50 \mathrm{~cm}$ above the soils and sediments it was previously anchored to. The weakened soil is below where the mat broke free

\section{Shear vane}

Stiff resistance to the penetration of the shear vane begins around $120+\mathrm{cm}$ in these marshes and so the reported data analyses are restricted to the $0-100 \mathrm{~cm}$ layer. The down core profiles of shear vane strength show that the soil strength of healthy marshes between 0 and $100 \mathrm{~cm}$ varied between 20 and $50 \mathrm{kPa}$, and was about $45 \mathrm{kPa}$ below $40 \mathrm{~cm}$. The profile of soil strength in the healthy marsh and in the eroding marsh overlapped in the upper $50 \mathrm{~cm}$, but then separated below the $50 \mathrm{~cm}$ depth (Fig. 3). The shear vane strength in this transition zone declined to about $20 \mathrm{kPa}$ below $60 \mathrm{~cm}$ soil depth. The soil strength averages $<30 \mathrm{kPa}$ at $60 \mathrm{~cm}$ and below, which is at the same soil depth of the mats floating immediately after Hurricane Isaac (Fig. 3). The strength at actual breakage could be lower then (we are not able to measure that), but the SE indicates a potential range before it does break, which could be at $15 \mathrm{kPa}$ (Fig. 3).

Mat up-lift

There is perennial and annual vegetative cover in the area impacted by the partially-treated sewage water
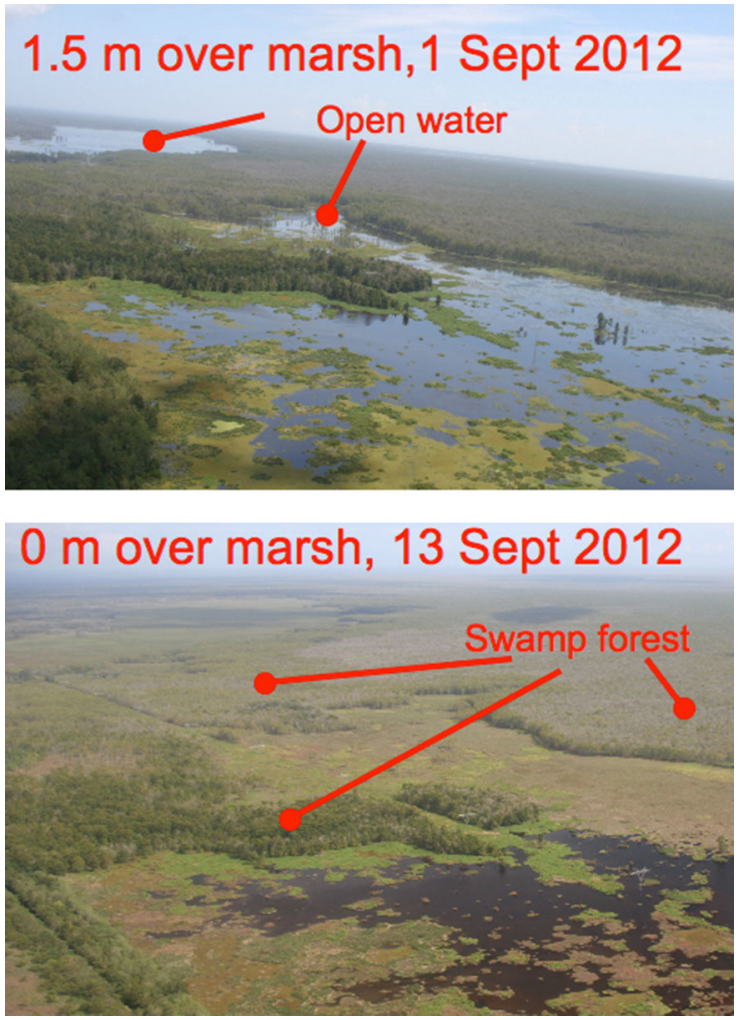

Fig. 4 Photographs of the study site looking eastward towards the control marsh, taken from a small airplane after Hurricane Isaac made landfall 28/29 August, 2012. Water covered the marsh on 1 September (upper photograph), and drained to marsh level by September 13th, 2012 (lower photograph). Note that there was water $1.5 \mathrm{~m}$ deep over the control marsh on 1 September, but that no marsh vegetation was evident. The bright green is floating aquatic vegetation

outfall (Fig. 1). The outfall area in 2012 was vegetated before the hurricane by some Azolla sp. and other floating algae accumulating at the shoreline, and floating annuals that shift locations. In contrast, all the four control marsh areas with perennial vegetation were covered with $>1 \mathrm{~m}$ water, and there was no floating vegetation visible there on 3 September 2010 (Fig. 4). These surrounding marshes appeared as an open water area during the high water event, but were as vegetated before Hurricane Isaac as they were after the water height returned to normal (Fig. 4), and remained this way as of September 2016.

\section{Discussion}

The scientific literature abounds with research findings indicating how various plants with a high $\mathrm{N}$ 
content decompose faster than plants with a low $\mathrm{N}$ content (Bodker et al. 2015). Nitrogen-enrichment enhances plant nitrogen content and accelerates decomposition plant material, including these marshes (Bodker et al. 2015). Phosphorus additions to various marsh plants results in, in the few cases investigated, less live root biomass production (Darby and Turner 2008) and lower soil strength (Turner 2011). The introduced partially-treated sewage has both nitrogen and phosphorous, and particularly nitrogen as ammonium which is $95 \%$ of the inorganic nitrogen in the effluent (unpublished results, RET). Kadlec and Wallace's (2009) encyclopedic review of treatment wetlands schematically summarized the effects of sewage on belowground biomass - natural wetlands have more root biomass that is deeper in the soil than in wetlands receiving sewage (Figs. 3.3 and 3.4 of that book), which is clearly an effect important to understand its consequences to the almost neutrally-buoyant organic soils in this study. The weakened soil strength, therefore, is a function not only of the quantity of belowground biomass, but also the quality of that biomass.

The enhanced organic decomposition and loss of root matter seems to be most significant at the bottom of the rooting depth, which is about $60 \mathrm{~cm}$ in this example. That is about the depth of weakened salt marsh soils exposed to the 2010 Deepwater Horizon oil spill (McClenachan et al. 2013) and also from experimental nutrient additions to coastal marshes (Turner 2011; Turner et al. 2009). Soil strength measurements in shallower depths may or may not reveal a response to nutrient additions in experiments ( $<50 \mathrm{~cm}$; Graham and Mendelssohn 2015; 0-20 cm, Hanson et al. 2016) and the soil matrix may make a difference (Kearney et al. 2015). This weakening of organic soils may not be obvious to the observer looking at only the aboveground vegetation, but can be a pervasive and long-lasting influence on marshes when the buoyant upward forces exceed the rooting strength.

Experiments examining how root biomass respond to nutrients may not capture significant factors when only biomass changes are considered. The larger roots act as metal tie-rods in the ecological cement to give structural strength to the organic whole. We agree with Mayence and Hester (2010) who suggested that "Quantifying the relationship between root length, diameter and tensile strength would benefit our understanding of the interaction between nutrient level and mat strength and is therefore warranted." and have work underway to investigate this aspect further. The soil strength measured with the shear vane represents a composited force of many roots, whereas the mat breaks away in small intervals as one or a few roots at a time. A change in the size distribution of roots to smaller ones involves a shift in the total soil strength. We did not measure root biomass by size classes, but Hanson et al. (2016) did for a 4 month mesocosm experiment with Spartina alterniflora. They found that the nutrient-enriched experimental units had a reduced number of coarse roots and rhizomes compared to the control units. These results support the conclusion that nutrient-poor soils encourage a larger belowground architectural framework to forage for nutrients and create stronger soils. Hanson et al. (2016) also found that the enriched sites had more finer roots that the unenriched sites, but carefully point out that fine roots decompose more rapidly than coarse roots or rhizomes (Morris et al. 2013; Wigand et al. 2014).

The buoyancy force under flooding is also a function of the force resulting from the submergence of aboveground tissue, which would be increased by the unmeasured upward force of trapped air bubbles (e.g., methane) within the plant's aerenchyma and in submerged mat, and perhaps released at higher rates with a drop in air pressure (Tokida et al. 2007). The bubble formation is more likely with warmer temperature and more nutrients. The plant's porous aerenchyma tissue expands as a result of nutrient enrichment adding more buoyancy that is also increased as more of the plant's basal tissues become submerged from the constant discharge of partially-treated sewage water. The combined force produces uplift on the soil block in which the plant community is anchored. A eutrophic marsh, for example, would more likely become a floating mat than an oligotrophic one (assuming all other factors equal). These rough estimations point to the uncertainty of the size of a surely larger upward pull on the mat-but, there is enough uplifting force to exceed the anchoring soil strength, hence its flotation $5 \mathrm{~cm}$ above the water.

Hogg and Wein (1988a) concluded that most of the buoyancy of floating Typha mats was comprised of bubble entrapment, which fluctuated seasonally, and not to tissue development which was about $10-20 \%$ of the buoyancy (Hogg and Wein 1988a). The 40-60 cm 
thick floating mats became detached from their substrate when water level was raised (Hogg and Wein 1988a). The increase in above-ground tissue with the addition of a limiting nutrient (nitrogen in their case) is, therefore, an added factor contributing to mat uplift. The production of gas would be enhanced by decomposition, which was temperature dependent (Hogg and Wein 1988b). There may also be a decreased density in roots, which remains an unmeasured factor.

The bulk density of mineral matter in coastal salt marshes is $2.4-2.5 \mathrm{~g} \mathrm{~cm}^{-3}$ (Callaway et al. 1997; Craft et al. 1993) and is directly related to soil bulk density, whereas the bulk density of organic matter is around 1.14-1.34 $\mathrm{g} \mathrm{cm}^{-3}$ in salt marshes and less than $0.1 \mathrm{~g} \mathrm{~cm}^{-3}$ in bogs (Krüger et al. 2015). Therefore, the soil mineral content is inversely related to its buoyancy-the higher the organic content, then the greater the buoyancy. This difference between mineral and organic density implies that organic soils may be more susceptible to enhanced nutrient-enriched buoyant uplift forces.

The reduction in soil strength occurs in the apparent absence of nutria grazing, and is in agreement with the opinion of the Louisiana Department of Wildlife and Fisheries's expert on nutria who was formally asked to make a determination whether nutria were the cause of the loss in this area. He concluded: "Based on biological review of available information, the Department does not consider nutria herbivory to be the primary cause of marsh degradation in the project area" and, they stated that they had never seen such rapid conversion solely due to nutria herbivory (http://www.saveourlake.org/ coastal-resources-HammondWorkshop.php\#hammond workshop).

Consideration should be given to the possibility that the partially-treated sewage can vary in toxicity strength and that toxic effluent spikes could be fatal or produce a profound stress to the trees and various species of marsh vegetation. The majority of cypress trees planted with protective collars (5000) within the marsh receiving partially-treated sewage either died, floated out of their anchorage, lodged over or manifested signs of abnormal growth (hypertrophy and stunted height). Some cypress trees planted in the firm soil of the pipeline embankment grew well, but other species on this spoil embankment died after the project began (Bodker et al. 2015).
The nutrient loading rate for this site is within the range for other sites whose soils are described as succumbing to soil strength losses. We can best make these comparisons using the cumulative nutrient loading, and include the synergistic effects of nitrogen and phosphorus additions (Darby and Turner 2008; Turner 2011). But annual estimates give a basis for comparison. Hunter et al. (2009) calculated the loading rates at Joyce WMA using the area of 4047 ha at $2.10 \mathrm{~g} \mathrm{~N} \mathrm{~m}^{2}$ year $^{-1}$, which was equivalent to $21 \mathrm{~kg} \mathrm{~N}$ ha year $^{-1}$. But the impact area where land turned to water is much smaller (122 ha) which equates to an annual total $\mathrm{N}$ loading rate of about $697 \mathrm{~kg} \mathrm{~N}$ ha year ${ }^{-1}$ over the impacted area. The loading rate would be even higher closer to the first exposure to effluent additions. A 10 ha exposure zone at the beginning of waste delivery, for example, would be $8499 \mathrm{~kg} \mathrm{~N}$ ha year ${ }^{-1}$. Furthermore, the average concentration of total nitrogen reported by Hunter et al. (2009) was $16.90 \mathrm{mg} \mathrm{N} \mathrm{L}^{-1}$, whereas we measured individual values 2 and 3 times higher than this value (unpublished).

These loading rates at the Joyce WMA marsh are within field conditions found elsewhere. The disintegrating marshes of the 5260 ha Jamaica Bay, NY, estuary have some of the highest total nitrogen loading rates at $1096 \mathrm{~kg} \mathrm{~N}$ ha year ${ }^{-1}$ (Benotti et al. 2007). The annual nitrogen loading for Deegan et al. (2012) longterm nutrient enriched salt marsh site was about $600 \mathrm{~kg} \mathrm{~N}$ ha year ${ }^{-1}$, and the consequences to the marsh loss became apparent three years later. The nitrogen load at the Caernarvon Mississippi River diversion for the entire flowpath area was $20 \mathrm{~kg} \mathrm{~N}$ ha year ${ }^{-1}$ (Hyfield et al. 2008), but the first $10 \%$ of the receiving area receives a load of $200 \mathrm{~kg} \mathrm{~N}$ ha year ${ }^{-1}$, and the impacts were not expressed until 19 years later during a high water event (Kearney et al. 2011). The impacts at the site we studied were apparent within one year of effluent application. One implication, then, is that the impacts might appear sooner at sites with higher loading rates or with longer periods of loading.

The total effect of the effluent loading continues to have a consequence to the carbon budget of the area. The 122 ha area converted to open water is about $100 \mathrm{~cm}$ deep, and so the amount of carbon released from the marsh is about 450 thousand $\mathrm{mt} \mathrm{C}$ year $^{-1}$. There are other issues, including that the un-managed distribution of pathogens into a nutrient- and organicrich system is a fertile growth medium for organisms 
potentially compromising the health of people and avians (Anza et al. 2014; Coyner et al. 2003; Spalding et al. 1993; Petrie et al. 2016), and that contaminates local streams - a subject that can be explored in more detail elsewhere. The consequences potentially apply to other marshes with significant vertical water movements and eutrophic conditions.

Wetland-to-open water conversion through the buoyant uplift and the subsequent movement of floating mats has a consequence to interpreting results from experiments using small exclosures used to experimentally test for herbivore grazing effects. Exclosures keep out the herbivore grazers, but also trap and maintain floating organic matter, perhaps to re-connect to the bottom layer. If the mat rises when disconnecting during flooding water, but cannot float away because of restraint by the exclosure wall, then the continuing presence of emergent vegetation could be interpreted as evidence for herbivore grazing outside the plot, whereas none happened. This problem of mis-interpretation is one arising from omitting a disturbed control as part of an experiment. A disturbed control allows access for herbivores, yet maintains the support offered by the wall structure, thereby testing for a 'cage effect' on emergent vegetation stability. We have seen exclosure cages at our study area that have one cage wall collapsed, but whose vegetation inside was intact; the area around it was devoid of emergent vegetation. In this case we concluded that herbivore grazing was insignificant.

We conclude that the well-being of this marsh was fatally compromised from the bottom-up influence of the nutrient enrichment. The decline in anchor strength, subsequent mat floatation, and mat decomposition is one way that marsh converts to open water. There are other factors involved, including plant community changes. Untangling the various other effects in a quantified manner can be complicated, and may require a variety of experiments, and many longterm observations (Vermaat et al. 2016).

Acknowledgements The data collection and analysis was supported by the Coastal Restoration and Enhancement through Science and Technology Program, Louisiana State University.

\section{Compliance with ethical standards}

Conflict of interest The authors declare that they have no conflict of interest.
Open Access This article is distributed under the terms of the Creative Commons Attribution 4.0 International License (http:// creativecommons.org/licenses/by/4.0/), which permits unrestricted use, distribution, and reproduction in any medium, provided you give appropriate credit to the original author(s) and the source, provide a link to the Creative Commons license, and indicate if changes were made.

\section{References}

Anza I, Vidal D, Laguna C et al (2014) Risk factors for avian botulism outbreaks in wetlands receiving effluents from urban wastewater treatment plants: eutrophication and bacterial pathogens. Appl Environ Microbiol 80:4251-4259

Barendregt A, Whigham D, Baldwin A (eds) (2009) Tidal freshwater wetlands. Backhuys Publishers, Leiden

Benotti MJ, Abbene M, Terracciano SA (2007) Nitrogen loading in Jamaica Bay, Long Island, New York: predevelopment to 2005. United States Geological Survey, Scientific Investigations Report 2007-5051. Washington, DC Available on line only @ http://pubs.usgs.gov/sir/2007/5051/

Berg R (2013) Tropical cyclone report Hurricane Isaac. National Hurricane Center, Washington, DC Available on line only @ http://www.nhc.noaa.gov/data/tcr/AL092012_Isaac.pdf

Boar RR, Crook CE, Moss B (1989) Regression of Phragmites australis reed swamps and recent changes of water chemistry in the Norfolk Broadland, England. Aquat Bot 35:41-55

Bodker JE, Turner RE, Tweel AW et al (2015) Nutrient-enhanced decomposition of belowground biomass of a freshwater wetland. Aquat Bot 127:44-52. doi:10.1016/j. aquabot.2015.08.001

Callaway JC, DeLaune RD, Patrick WH Jr (1997) Sediment accretion rates from four coastal wetlands along the Gulf of Mexico. J Coastal Res 13:181-191

Chabreck RH (1972) Vegetation and soil characteristics of the Louisiana coastal region. Louisiana State University Agricultural Experiment Station Bulletin 664, Baton Rouge

Coyner DF, Spalding MG, Forrester DJ (2003) Epizootiology of Eustrongylides ignostus in Florida: transmission and development of larvae in intermediate hosts. J Parasit 89(2):290-298

Craft CB, Seneca ED, Broome SW (1993) Vertical accretion in microtidal regularly and irregularly flood estuarine marshes. Estuar Coastal Shelf Sci 27:371-386

Cypert E (1972) The origin of houses in the Okefenokee prairies. Am Midland Natur 87:448-458

Darby FA, Turner RE (2008) Below- and aboveground biomass of Spartina alterniflora: response to nutrient addition in a Louisiana salt marsh. Estuar Coasts 31:326-334. doi:10. 1007/s12237-008-9037-8

Deegan LA (2002) Lessons learned: the effects of nutrient enrichment on the support of nekton by seagrass and salt marsh ecosystems. Estuaries 25:727-742 
Deegan LA, Johnson DS, Warren RS et al (2012) Coastal eutrophication as a driver of salt marsh loss. Nature 490:388-392

Denno RF, Gratton C, Dobel H, Finke DL (2003) Predation risk affects relative strength of top-down and bottom-up impacts on insect herbivores. Ecol 84(4):1032-104415

Enríquez S, Duarte CM, Sand-Jensen K (1993) Patterns in decomposition rates among photosynthetic organisms: the importance of detritus C:N: P content. Oecologia 94:457-471

Graham SA, Mendelssohn IA (2015) Coastal wetland stability maintained through counterbalancing accretionary responses to chronic nutrient enrichment. Ecol 95:3271-3283

Hanson A, Johnson R, Wigand C et al (2016) Responses of Spartina alterniflora to multiple stressors: changing precipitation patterns, accelerated sea level rise, and nutrient enrichment. Estuar Coasts 39:1376-1385. doi:10.1007/ s12237-016-0090-4

Hogg EH, Wein RW (1988a) The contribution of Typha components to floating mat buoyancy. Ecol 69:1025-1031

Hogg EH, Wein RW (1988b) Seasonal change in gas content and buoyancy of floating Typha mats. J Ecol 76:1055-1068

Hunter R, Lane R, Day JW et al (2009) Forested wetlands assimilating treated municipal effluent. Environ Manag 44:865-873. doi:10.1007/s00267-009-9348-y

Hyfield ECG, Day JW, Cable JE et al (2008) The impacts of reintroducing Mississippi River water on the hydrologic budget and nutrient inputs of a deltaic estuary. Ecol Engin 32:347-359

Ialeggio JS, Nyman JA (2014) Nutria grazing preference as a function of fertilization. Wetlands 34:1039-1045

Kadlec RH, Wallace S (2009) Treatment wetlands. CRC Press, Boca Raton

Kearney MS, Riter CA, Turner RE (2011) Freshwater diversions for marsh restoration in Louisiana: twenty-six years of changing vegetative cover and marsh area. Geophys Res Lett 38:L16405. doi:10.1029/2011GL047847

Kearney MS, Riter CA, Turner RE (2015) Comment on: "Integrating successional ecology and the delta lobe cycle in wetland research and restoration" by Nyman (2014). Estuar Coasts 38:1821-1823. doi:10.1007/s12237-0149921-3

Keddy PA (2011) Wetland ecology: principles and conservation, 2nd edn. Cambridge University Press, Cambridge

Kominoski JS, Rosemond AD, Benstead JP et al (2015) Low-tomoderate nitrogen and phosphorus concentrations accelerate microbially driven litter breakdown rates. Ecol Appl 25:856-865. doi:10.1890/14-1113.1

Krüger JP, Leifeld J, Glatzel S et al (2015) Biogeochemical indicators of peatland degradation-a case study of a temperate bog in northern Germany. Biogeosci $12: 2861-2871$

Liu J, Wu N, Wang H, Sun J et al (2016) Nitrogen addition affects chemical compositions of plant tissues, litter and soil organic matter. Ecology 97(7):1796-1806

Mander Ü, Dotro G, Ebie Y et al (2014) Greenhouse gas emission in constructed wetlands for wastewater treatment: a review. Ecol Engin 66:19-35
Mayence CE, Hester MW (2010) Growth and allocation by a keystone wetland plant, Panicum hemitomon, and implications for managing and rehabilitating coastal freshwater marshes, Louisiana, USA. Wetlands Ecol Manage 18:149-163

McClenachan G, Turner RE, Tweel AT (2013) Effects of oil on the rate and trajectory of Louisiana marsh shoreline erosion. Environ Res Lett 8:044030

Mitsch WJ, Gosselink JG (2015) Wetlands, 5th edn. Wiley, Hoboken

Morris JT, Shaffer GP, Nyman JA (2013) Brinson review: perspectives on the influence of nutrients on the sustainability of coastal wetlands. Wetlands 33:975-988

Petrie B, Barden R, Kasprzyk-Hordern B (2016) A review on emerging contaminants in wastewaters and the environment: current knowledge, understudied areas and recommendations for future monitoring. Water Res 72:3-27

Reddy KR, Delaune RD (2008) Biochemistry of wetlands. CRC Press, New York

Rosemond AD, Benstead JP, Bumpers PM et al (2015) Experimental nutrient additions accelerate terrestrial carbon loss from stream ecosystems. Science 347:1143-1145

Spalding MG, Bancroft GT, Forrester DJ (1993) The epizootiology of eustrongylidosis in wading birds (Ciconiiformes) in Florida. J Wildlife Dis 29:237-249

Swarzenski CM, Doyle TW, Fry B et al (2008) Biogeochemical response of organic-rich freshwater marshes in the Louisiana delta plain to chronic river water influx. Biogeochemistry 90:49-63. doi:10.1007/s10533-008-9230-7

Tokida T, Miyazaki T, Mizoguchi M (2007) Falling atmospheric pressure as a trigger for methane ebullition from peatland. Global Biogeochem Cycles. doi:10.1029/ 2006GB002790

Turner RE (2002) Element ratios in aquatic food webs. Estuaries 25(33):1084-1093. doi:10.1007/s12237-010-9341-y

Turner RE (2011) Beneath the wetland canopy: loss of soil marsh strength with increasing nutrient load. Estuar Coasts 33:1084-1093. doi:10.1007/s12237-010-9341-y

Turner RE, Howes BL, Teal JM et al (2009) Salt marshes and eutrophication: an unsustainable outcome. Limnol Oceanogr 54:1634-1642

United States Army Corps of Engineers (USACOE) (2013) Hurricane Isaac with and without 2012 100-year hurricane storm damage risk reduction system evaluation. Final Report, New Orleans District. http://www.mvn.usace.army. mil/Portals/56/docs/PAO/20130208HurrIsaacW-WO2012 HSDRRS.pdf

Vermaat JE, Box B, van der Burg P (2016) Why do reed beds decline and fail to re-establish? A case study of Dutch peat lakes. Freshwater Biol 61:1580-1589

Webster JR, Benfield EF (1986) Vascular plant breakdown in freshwater ecosystems. Annu Rev Ecol Syst 17:567-594

Wigand C, Roman CT, Davey E et al (2014) Below the disappearing marshes of an urban estuary: historic nitrogen trends and soil structure. Ecol Appl 24:633-649. doi:10. 1890/13-0594.1 